2017-06

\title{
Editorial Introduction: Fourth Planetary Dunes Workshop Special Issue
}

Chojnacki, M

http://hdl.handle.net/10026.1/9894

10.1016/j.aeolia.2017.05.003

Aeolian Research

Elsevier BV

All content in PEARL is protected by copyright law. Author manuscripts are made available in accordance with publisher policies. Please cite only the published version using the details provided on the item record or document. In the absence of an open licence (e.g. Creative Commons), permissions for further reuse of content should be sought from the publisher or author. 


\section{Editorial Introduction: Fourth Planetary Dunes Workshop Special Issue}

Matthew Chojnacki ${ }^{*}$, and Matt W. Telfer ${ }^{2}$.

Manuscript for Submission to Aeolian Research

Special Issue: Aeolian Research Special Issue for the Fourth International Planetary Dunes Workshop

*Corresponding Author:

Matthew Chojnacki

Lunar and Planetary Lab

University of Arizona

1541 E. University Blvd.

Tucson, AZ 85721-0063 USA

office phone: $\underline{520-626-0752}$

fax: 520-626-8998

email: chojan1@pirl.lpl.arizona.edu

${ }^{1}$ Lunar and Planetary Laboratory, University of Arizona, Tucson, AZ, 85721, USA;

${ }^{2}$ SOGEES, University of Plymouth, Drake Circus, Plymouth, Devon. PL4 8AA. UK. 
2

3

4

5

10

11

12

13

14

15

16

17

18

19

20

21

22

23

24

25

26

27

28

29

30

31

32

33

34

35

36

37

38

39
Integrating

!, Idaho (see

$\mathrm{n}$ two and a

to Bruneau

sits created

processes).

Earth, Mars,

ose of this

ew ideas and

ng programs,

sp website

;ome of the

an studies of series were Ian (2014). A also reported sible without $\downarrow s$, the other Lori Fenton, ession chairs, and Bruneau

ive input and ue, provided nanager, was owledge Tim or the papers nsible for the

Id targets for dies and the e of repeatrascent areas bedforms in erasimenko). on planetary vell-attended 
been widely

connaissance ext given the uriosity rover traterrestrial

45

46

47

48

49

50

51

52

53

54

55

56

57

58

59

60

61

62

63

64

65

66

67

68

69

70

71

72

73

74

75

76

77

78

79

; can reveal a them. Much ial analogues gh-resolution orms termed tion between ose of small e correlation e authors to lust flows of

without easy unes of Mars. nent (HiRISE) -e extraction srived which ! features. As isors such as available, this ong-standing apotre et al. provides an olian science loration and and Johnson 
89

90

91

92

93

94

95

96

97

98

99

100

101

102

103

104

105 -resolution (1 e field in the ? orientation. ie field, with e orientation ts that, away rmative wind

to be active 11; Chojnacki $h$ a variety of $n$ this special is correlated ds over many as found (i.e. it devil tracks tor of dune vhether early , 2015) were ibed 13 active se dune fields of crest fluxes northeasterlyanalysis had

field of White dunes partially low density of lafic rocks (on ; sorting, and ieralogies. By nsity grains in possibility of illustrate how environments The article by
Formatted: Danish Field Code Changed 
Irrent state of Those authors ies (e.g., wind ta and surface hose missions. uch as climate layed a role in (2017) take a the potential ilarities of the 2s of resultant - collaboration

ts of planetary ty has studied candidates on sse authors go I a consistent 'pe (e.g., flyby that planetary (which, whilst -up trajectory llowing a topnce of aeolian ique different

railable to the $y$ researchers. ! with specific accumulation, $t$ despite such ant dunes and nizable across fectiveness of nes Workshop I Special Issue I International ge, Utah (see ! next meeting tion in aeolian 
172

190

191

192

193 nality) suggest lian processes

tion of aerial

5 Journal of 551-560.

Zhojnacki, M., ds in Aeolian onal Planetary Id Data, Lunar

4. Preliminary the 45th Lunar 2 , Houston, p.

$\therefore$ Insights into n Research.

Radebaugh, J., : on planetary 1.2010.04.007

S., Golombek, Stantzos, N., gy $40,31-34$.

$s$ as compared morphologies, 96-142.

bservations of lum, Mars. J. 
I III, J.F., 2015.

m, Mars; new

i) 275-290.

196

197

198

sediment flux

199

) Research.

200

201

202

203

D., 2016. Our n of dunes on ग1

204

azin, P., 2016.

ands National

Research.

207

208

s on Mars. J.

209

dges on Mars.

211

I., Becker, K.J., M., Keszthelyi, Eliason, E.M., ipping of Mars hoenix landing

216

217

olian deposits 5.001

., Rubin, D.M., Iges, N.T., Des J.W., Mischna, 6. Large wind : 353, 55-58.

:.J., Delamere, ‘, R.L., Mellon, econnaissance 
Geophys. Res.

lunes: Possible

232 shys. Res. Lett.

In a Variety of

Ig meter-scale od analogues?

ssue, and the 230, 1-4. 256 